\title{
Extension Shelf Life of Domiati Cheese Made by Using Some of Natural Preservatives
}

\author{
Karima A.H. Saleh ${ }^{1}$ and O. S. F. Khalil ${ }^{2}$ \\ ${ }^{1}$ Dairy Science Dept., Faculty of Agriculture, Minia University, Egypt. \\ ${ }^{2}$ Dairy science and Technology Department, Faculty of Agriculture and Natural \\ Resources, Aswan University, Egypt . \\ Email: Osama.safwat@agr.aswu.edu.eg
}

Received on: 9/1/2019

Accepted for publication on: 3/3/2019

\begin{abstract}
:
There is growing interest in natural ingredients that can be used as preservatives in the food industry. Significant attention is dedicated to propolis and essential oils as they often exhibit antioxidant and antimicrobial properties. Domiati cheese fortified with propolis, ginger and thyme were evaluated. The cheeses were analyzed fresh and during ripening for their chemical composition, microbiological and organoleptic properties. The addition of $5 \% \& 10 \%$ propolis, $0.5 \%$ ginger and $0.5 \%$ thyme caused decreased in $\mathrm{pH}$ value but less than the control. Thyme and ginger fortified cheese caused increase in the WSN, NPN and (T.V.F.A) contents in all cheeses. The addition of $5 \%, 10 \%$ propolis, $0.5 \%$ ginger and $0.5 \%$ thyme respectively, had the highest effect on total bacterial count. Which indicate its antimicrobial effect on cheese microflora. Moulds, yeasts and Escherichia coli (E. coli), were not detected in treated cheese through ripening. All cheese samples made with propolis, ginger and thyme had acceptable appearance and body \& texture during ripening. Propolis and essential oils can be used to improve the quality of Domiati cheese and can be used as natural preservatives to increase its shelf life up to 60 days of ripening at room temperature or at $4^{\circ} \mathrm{C} \pm 2$.
\end{abstract}

\section{Keywords: Domiati Cheese, Shelf Life, Propolis, Ginger, Thyme}

\section{Introduction:}

Cheese is a vital fermented dairy product which had a major role in human nutrition for centuries. Cheese is perhaps the oldest processed food known to mankind and one of the most ubiquitous food stuffs in the world (Zakaria et al., 2012).

Domiati cheese is one of the most popular white pickled cheese varieties consumed in Egypt. It differs chiefly from other pickled cheese varieties such as Feta, Brinza and Telema cheese. The cheese is made from either Cow or Buffalo whole milk or a mixture of both. The salted milk can be curdled fresh or some- times after pasteurization, without the addition of any starter cultures. The cheese can be consumed either fresh or after pickling in salted whey for up to 2 to 4 months (Zhang et al., 2003).

Yeasts and moulds play an important role in the spoilage of Domiati cheese. It also may impair public health due to the presence of mycotoxins which cause carcinogenic health problems. The microbial quality and safety of Domiati cheese is the major area of concern for producers and consumers. Therefore, there is a need to develop improve the Domiati cheese quality, and increasing its shelf life. The Institute of Food 
Science and Technology defined shelf life as " the period of time during which the food product will (1) remain safe (2) be certain to retain its desired sensory, chemical, physical, microbiological and functional characteristics, (Nicoli, 2012).

The stability of short shelf life dairy products depends on the moderation of the growth of and subsequent degradation by spoilage microorganisms. In contrast, the shelf life of intermediate and long life dairy products is largely determined by enzymatic degradation or by chemical deterioration (Kilcast and Subramaniam, 2011).

The addition of preservatives is one of the simple and oldest ways to extension shelf life of cheese. Preservatives in cheese processing may help to retard alterations caused by growth of microorganisms, or enable physical properties, chemical composition and original nutritional value to remain unaffected (Jalilzadeh et al., 2015).

The most accepted ways to extend the shelf life of the dairy products is the use of bio- preservatives (Ismail et al., 2006 and Dabiza, 2006). Garlic and ginger have been widely known to improve lipid metabolism, promoting the circulation of blood, preventing cardiovascular diseases and immuno-potentiating with anticancer activity (Lawson, 1993).

Ginger is a great natural preservative and bactericide. Ginger extract is effective in killing salmonella, and inhibits the fungi that produce aflatoxin.

Essential oil of thyme is a good radical scavenging, antibacterial and antifungal activities (Oleg Maksimov, 2017).

Propolis is a natural resinous bee product collected by honeybee workers, has gained popularity as an alternative medicine or food for health amelioration and disease prevention in various parts of the world.

So, the aim of this study was to evaluate the potential of propolis extracts and essential oils namely ginger and thyme as preservatives and its efficacy on the storage quality of Domiati cheese.

\section{Materials and Methods \\ Materials:}

Milk: Fresh mixed cows and buffalos' milk (1:1) was obtained from Animal Production Department, Faculty of Agriculture Minia University.

\section{Natural preservatives:}

Propolis: Propolis was collected from hybrid honey bee colonies at Minia Governorate. The collected propolis was kept at refrigerator until further processing propolis solution $5 \%$ and $10 \%(\mathrm{w} / \mathrm{v})$.

Extraction of propolis: Ethanolic extract of propolis (EEP) were obtained using the methodology of Paviani et al. (2009) where $3 \mathrm{~g}$ of crude propolis was mixed with $10 \mathrm{~mL}$ of ethanol and stirred using a magnet stirrer for 1 day at room temperature.

The insoluble portion was then separated by filtration; the filtrates kept in a freezer at $-10{ }^{\circ} \mathrm{C}$ overnight and then filtered again to reduce the wax content of the extracts.

Essential oils: Two types of essential oils namely ginger and thyme were purchased from local market (Aswan Governorate, Egypt) and 
stored at $7^{\circ} \mathrm{C}$ (Ismael and pierson, 1990).

Chemicals: All chemicals used in this study were of analytical grade supplied by BDH, Sigma and Prolabo chemical companies. Distilled water was used for the preparation of all solution, Pyrex glassware were used throughout.

Rennet: Standard calf liquid rennet obtained from local market was used at a rate of $1.0 \mathrm{ml} / \mathrm{L}$ milk

Salt: Commercial sodium chloride was obtained from El-Naser Company for salt Alexandria, Egypt.

Cheese manufacture: Domiati cheese was made from raw milk as described by Abd El-kader (2003). The salt was added at rate of $5 \%$ $(\mathrm{w} / \mathrm{w})$ to all milk before renneting using commercial animal rennet. Five treatments of cheese were carried out as fallows:- The first portion was kept untreated and served as control called (c). - The second and third portions were varnished by $5 \%$ and $10 \%$ concentration of extract of propolis respectively called $(\mathrm{T} 1, \mathrm{~T} 2)$.- The fourth and fifth portions were mixed with ginger and thyme oils at ratio of 0.5 $\%$ respectively called $(\mathrm{T} 3, \mathrm{~T} 4)$. Samples of cheese were analyzed when Fresh day and after 15, 30 and 60 days of ripening period.

\section{Chemical Analyses:}

PH measurements: Cheese $(10$ g) was macerated in a mortar with 10 $\mathrm{ml}$ of distilled water and the $\mathrm{pH}$ was measured using a $\mathrm{pH}$ meter (Jenway model 3510).

Titratable acidity: Titratable acidity of cheese was determined according to A.O.A.C. (2000).
Moisture content: Moisture content was determined according to A.O.A.C.(2005).

Fat determination: Cheese fat were determined by using Gerber according to the method described by Ling (1963).

Salt determination: Salt was determined according to Simov (1980).

Protein determination: The total nitrogen (TN\%) content in Domiati cheese was measured using micro-kjeldahl method according to A.O.A.C. (2005).

Water soluble nitrogen: The water soluble nitrogen (WSN) content in cheese was determined according to Kuchroo and Fox (1982).

Non-protein nitrogen: nonprotein-nitrogen (NPN) was determined according to Ling (1963).

Lipolysis in cheese: Lipolysis in cheese during ripening was followed by determined the changes in the volatile free fatty acids using the method described by Kosikowski (1982).

Ash: Ash contents were determined in muffle furnace at $550^{\circ} \mathrm{C}$ over night. According to Association of Official Analytical Chemists (A.O.A.C., 2000). The obtained ash calculated as percent of samples weight.

Microbiological Analyses: All samples were examined for total bacterial count (TBC), E. coli, moulds \& yeasts according to American Public Health Association (APHA, 1992). All microbiological and chemical analysis of Domiati cheese were analyzed in duplicate.

Sensory Evaluation: Domiati cheese samples were sensorial evalu- 
ated for fresh, 2, 4, and 8 weeks according to Papas et al. (1996). The evaluation was carried out by the score panel of the staff members of Dairy Science and Technology Department, Faculty of Agriculture Natural Resources, Aswan University, Egypt.

\section{Results and Discussion:}

Chemical properties: The results in Table (1\&2) showed the chemical composition of Domiati cheese at $4{ }^{\circ} \mathrm{C} \pm 2$ and at room temperature.

As shown in Table (1\&2) there were differences in $\mathrm{pH}$ and acidity between fresh and ripened cheese. All cheese samples at room temperature had the lower $\mathrm{PH}$ values and higher acidity than cheese at $4{ }^{\circ} \mathrm{C} \pm 2$. The addition of $0.5 \%$ ginger, $0.5 \%$ thyme, $5 \%$ propolis and $10 \%$ propolis caused decreased in $\mathrm{pH}$ but less than the control. It could be seen from the results indicated in Table $(1 \& 2)$ the lowest $\mathrm{pH}$ value were detected in control treatment. The decrease was proportional to the addition ratio. However, the decreasing in $\mathrm{pH}$ values was higher during ripening. The decrease was more pronounced in samples ripenied at room temperature. At the end of the ripening period, all cheeses had closer $\mathrm{pH}$ values. The reduction in $\mathrm{pH}$ value during ripening could be attributed to the growth of microflora and enzymes in the product, which leads to hydrolysis of lactose to some acids. This results are in agreement with those of Tamime et al. (1990) and Awad et al. (2003).

Table 1. Chemical composition of Domiati cheese as affected by certain natural preservatives during storage period at $4^{\circ} \mathrm{C} \pm 2$.

\begin{tabular}{|c|c|c|c|c|c|c|c|}
\hline \multirow{2}{*}{ Treatments } & \multirow{2}{*}{ Days } & \multicolumn{7}{|c|}{ At 4 $\mathbf{C}$. 2 } \\
\cline { 3 - 7 } & & PH & Acidity & Moisture & Fat / DM & Salt / M & Ash \\
\hline C & Fresh & 6.2 & 0.25 & 57.03 & 51.20 & 5.24 & 4.58 \\
& 15 & 5.9 & 0.55 & 56.12 & 54.70 & 5.50 & 4.66 \\
& 30 & 5.6 & 0.65 & 54.37 & 56.98 & 6.03 & 4.92 \\
& 60 & 5.4 & 0.95 & 51.90 & 59.25 & 6.67 & 5.15 \\
\hline T1 & Fresh & 6.1 & 0.30 & 57.30 & 54.89 & 5.07 & 4.79 \\
& 15 & 6.0 & 0.40 & 56.09 & 56.00 & 5.49 & 4.88 \\
& 30 & 5.9 & 0.60 & 53.92 & 58.59 & 6.08 & 5.00 \\
& 60 & 5.6 & 0.70 & 51.88 & 61.31 & 6.63 & 5.17 \\
\hline T2 & Fresh & 6.1 & 0.35 & 58.73 & 56.35 & 4.97 & 4.70 \\
& 15 & 6.0 & 0.45 & 56.88 & 57.98 & 5.43 & 4.82 \\
& 30 & 5.8 & 0.55 & 54.08 & 59.87 & 6.06 & 4.95 \\
& 60 & 5.6 & 0.75 & 52.14 & 62.35 & 6.52 & 5.10 \\
\hline T3 & Fresh & 6.1 & 0.30 & 57.58 & 61.71 & 5.01 & 4.86 \\
& 15 & 5.9 & 0.55 & 55.22 & 63.95 & 5.42 & 4.94 \\
& 30 & 5.7 & 0.65 & 52.14 & 66.28 & 5.99 & 5.09 \\
& 60 & 5.5 & 0.75 & 50.65 & 67.87 & 6.51 & 5.22 \\
\hline T4 & Fresh & 6.1 & 0.30 & 58.94 & 63.32 & 4.92 & 4.80 \\
& 15 & 6.0 & 0.50 & 56.45 & 65.34 & 5.40 & 4.90 \\
& 30 & 5.8 & 0.65 & 53.02 & 67.46 & 5.72 & 5.02 \\
& 60 & 5.6 & 0.75 & 51.62 & 68.92 & 6.63 & 5.18 \\
\hline
\end{tabular}

Fat / DM= Fat / Dry Matter, Salt / M = Salt in Moisture. 
Table 2. Chemical composition of Domiati cheese as affected by certain natural preservatives during storage period at room temperature.

\begin{tabular}{|c|c|c|c|c|c|c|c|}
\hline \multirow{2}{*}{ Treatments } & \multirow{2}{*}{ Days } & \multicolumn{6}{|c|}{ At room temperature } \\
\cline { 3 - 7 } & & PH & Acidity & Moisture & Fat / DM & Salt / M & Ash \\
\hline C & Fresh & 6.2 & 0.25 & 57.03 & 51.20 & 5.24 & 4.58 \\
& 15 & 5.2 & 1.70 & 46.22 & 56.70 & 6.68 & 4.27 \\
& 30 & 4.9 & 1.95 & 44.64 & 56.60 & 7.11 & 4.47 \\
& 60 & 4.5 & 2.15 & 42.33 & 57.22 & 7.74 & 4.82 \\
\hline T1 & Fresh & 6.1 & 0.30 & 57.30 & 54.89 & 5.07 & 4.79 \\
& 15 & 5.2 & 1.70 & 47.35 & 58.88 & 6.71 & 4.44 \\
& 30 & 5.0 & 1.75 & 46.12 & 59.39 & 7.11 & 4.77 \\
& 60 & 4.9 & 1.90 & 44.91 & 61.17 & 7.70 & 5.09 \\
\hline T2 & Fresh & 6.1 & 0.35 & 58.73 & 56.35 & 4.97 & 4.70 \\
& 15 & 5.1 & 1.75 & 47.02 & 59.43 & 6.57 & 4.46 \\
& 30 & 5.0 & 1.80 & 46.08 & 60.27 & 7.11 & 4.82 \\
& 60 & 4.9 & 1.90 & 44.88 & 63.50 & 7.57 & 5.14 \\
\hline T3 & Fresh & 6.1 & 0.30 & 57.58 & 61.71 & 5.01 & 4.86 \\
& 15 & 5.3 & 1.60 & 50.29 & 62.12 & 6.14 & 4.40 \\
& 30 & 5.2 & 1.70 & 46.24 & 63.24 & 7.35 & 4.86 \\
& 60 & 5.1 & 1.85 & 44.78 & 64.29 & 7.72 & 5.16 \\
\hline T4 & Fresh & 6.1 & 0.30 & 58.94 & 63.32 & 4.92 & 4.80 \\
& 15 & 5.3 & 1.65 & 50.65 & 64.84 & 6.27 & 4.63 \\
& 30 & 5.1 & 1.75 & 47.04 & 65.14 & 7.35 & 4.92 \\
& 60 & 5.0 & 1.85 & 45.71 & 66.31 & 7.78 & 5.39 \\
\hline
\end{tabular}

Acidity increased rapidly during ripening within 15 days then, gradually until the end of the ripening period. Cheese samples which kept at 4 ${ }^{\circ} \mathrm{C}$ had lower acidity at fresh and during ripening compared to others cheese which kept at room temperature. It could be concluded that room temperature increased the rate of acid development during ripening as a results for active effect on microbial flora of cheese.

Data in Table (1\&2) show the changes in the chemical composition of Domiati cheese samples during the ripening process which was extended up to 60 days. All cheese samples showed a gradual loss of moisture over the ripening period, perhaps through leakages of whey. However, a gradual increase in the fat / dry matter and salt in moisture content were apparent over the ripening period.

WSN/TN and NPN/TN: were used as index of proteolysis. Thyme and ginger affected protein proteolysis (WSN/TN) and (NPN/TN) ratio of Domiati cheese. Thyme fortified cheese caused increase in the WSN and NPN content, which indicate its great proteolytic activity (Fig 1, 2, 3 $\& 4)$. Cheese samples at room temperature had the highest percentage of WSN/TN.

The degree of proteolysis in all cheese increased during ripening. But it was more pronounced in the thyme extract fortified cheese than the control and other additives. 


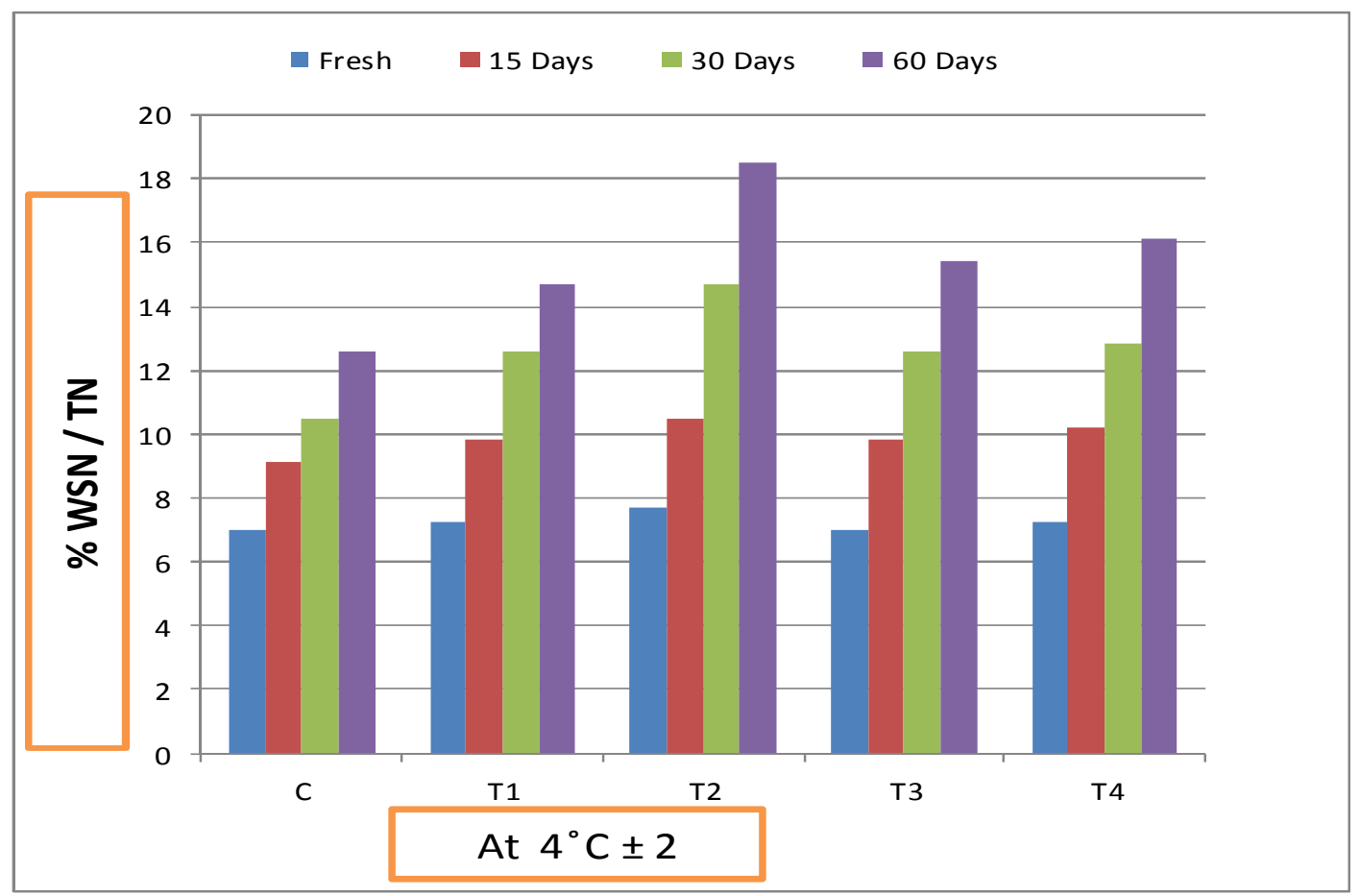

Fig (1): Water soluble nitrogen/ total nitrogen percent of resultant Domiati cheese held at $4{ }^{\circ} \mathrm{C} \pm 2$ For 60 days.

The increase in proteolysis could be attributed to the proteolytic activity in thyme, ginger and propolis extract, respectively. Meanwhile, our results are in agreement with those reported by Abd El-Aziz et al. (2012), Awad et al. (2003), Abd ElAziz et al. (2010) and El-Sayed (2017). 


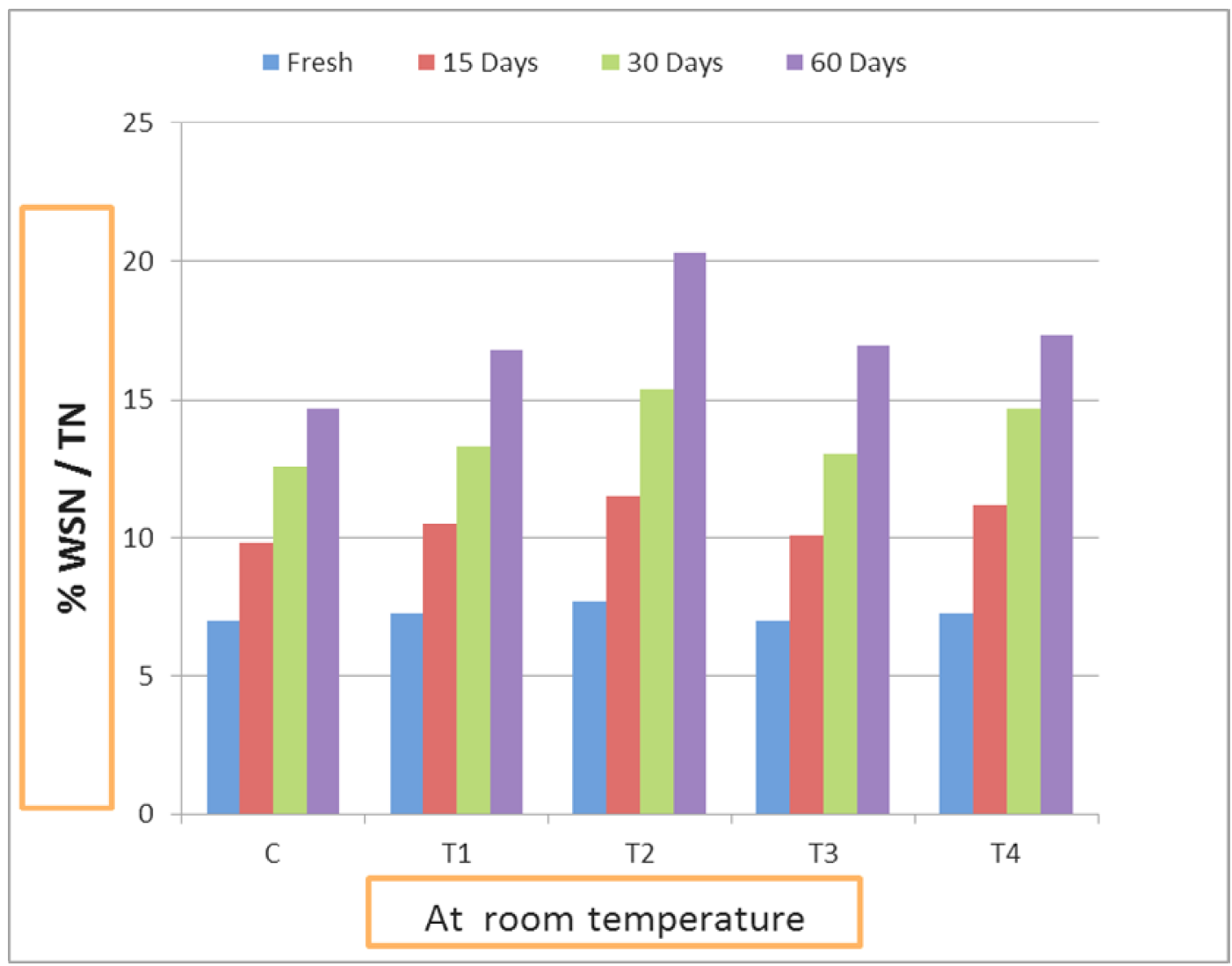

Fig (2): Water soluble nitrogen/ total nitrogen percent of resultant Domiati cheese held at room temperature For 60 days.

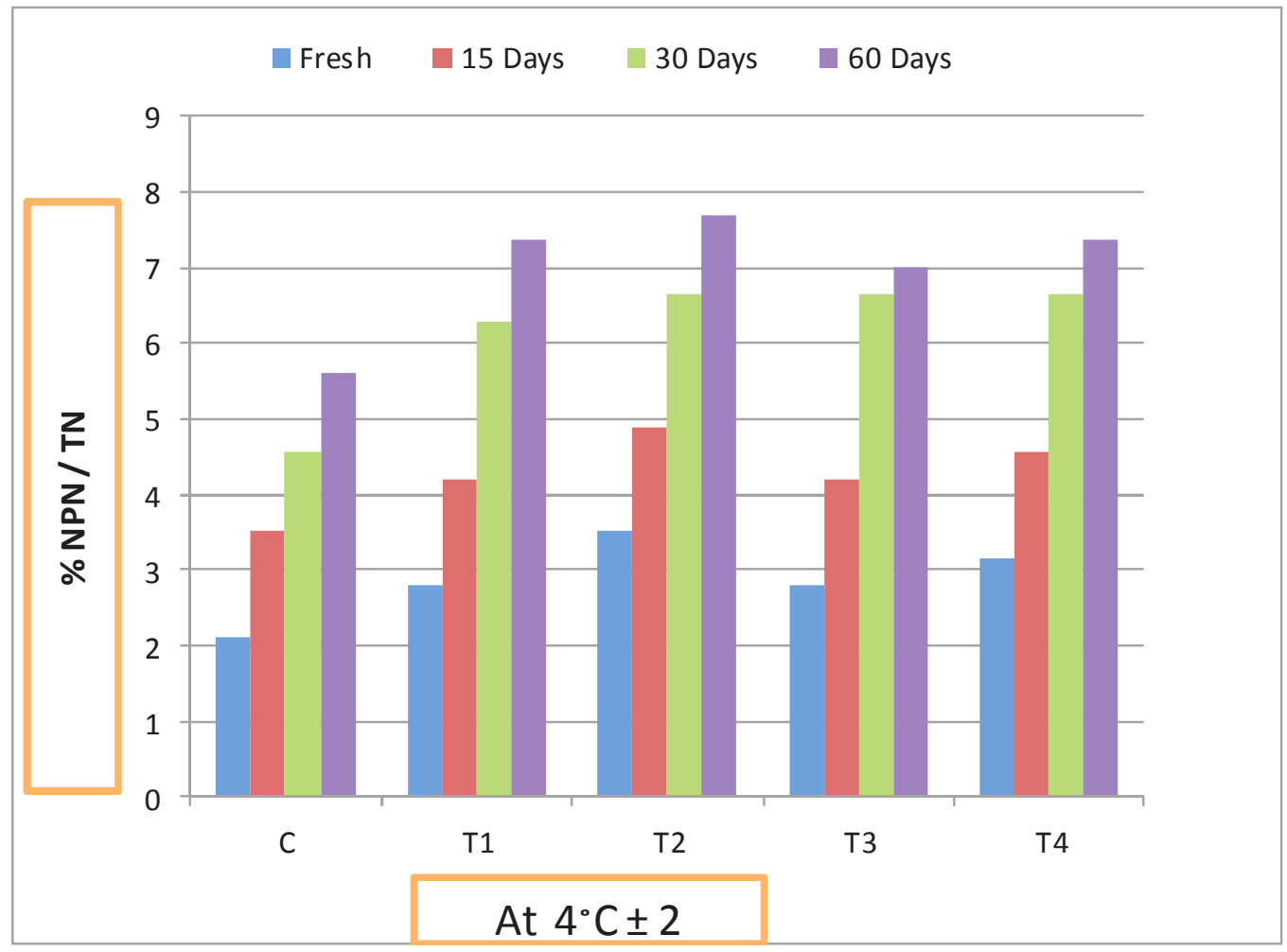

Fig (3): Non protein nitrogen/ total nitrogen percent of resultant Domiati cheese held at $4^{\circ} \mathrm{C} \pm 2$ For 60 days. 


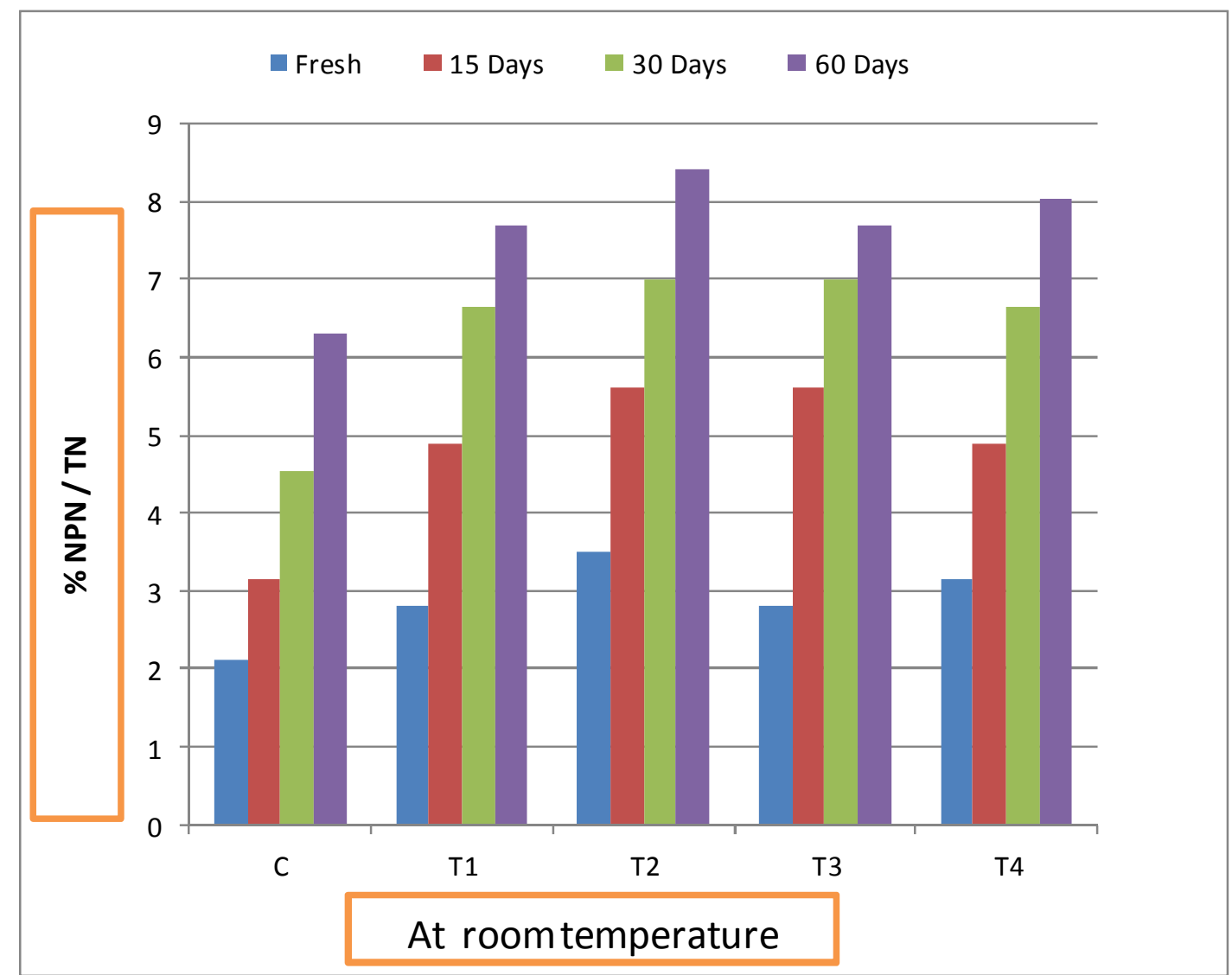

Fig (4): Non protein nitrogen/ total nitrogen percent of resultant Domiati cheese held at room temperature For 60 days.

Total volatial fatty acids T.V.F.A. content of all cheese sam(T.V.F.A): The changes in the ples markedly increased at the first T.V.F.A of fresh cheese and during month and followed by gradual inripening are shown in Fig (5\&6). The crease until the end of storage period. 


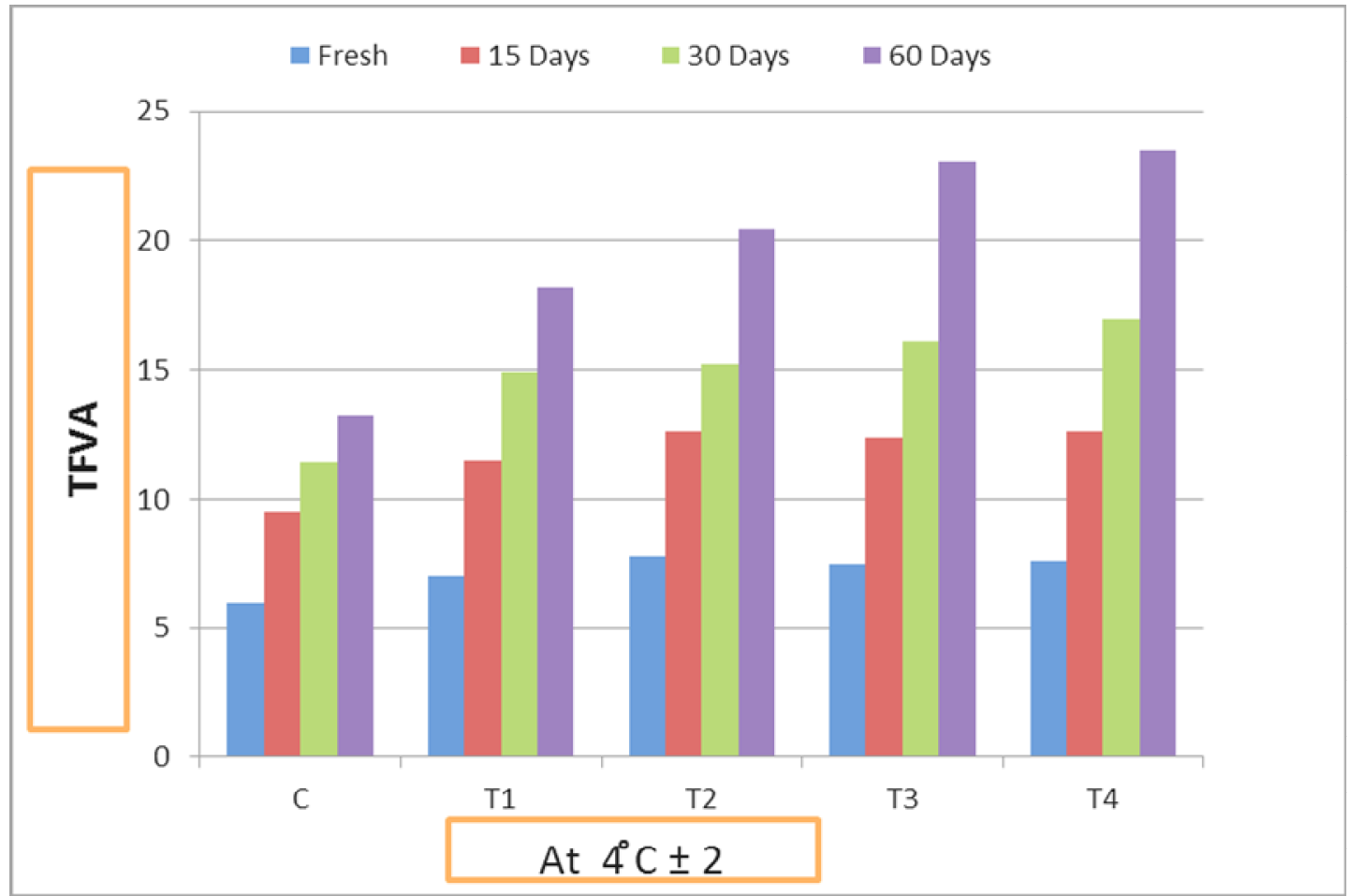

Fig (5): Total volatial fatty acids of resultant Domiati cheese held at $4{ }^{\circ} \mathrm{C} \pm 2$ For 60 days $(0.1 \mathrm{~N} \mathrm{NaOH} / 100 \mathrm{~g})$.

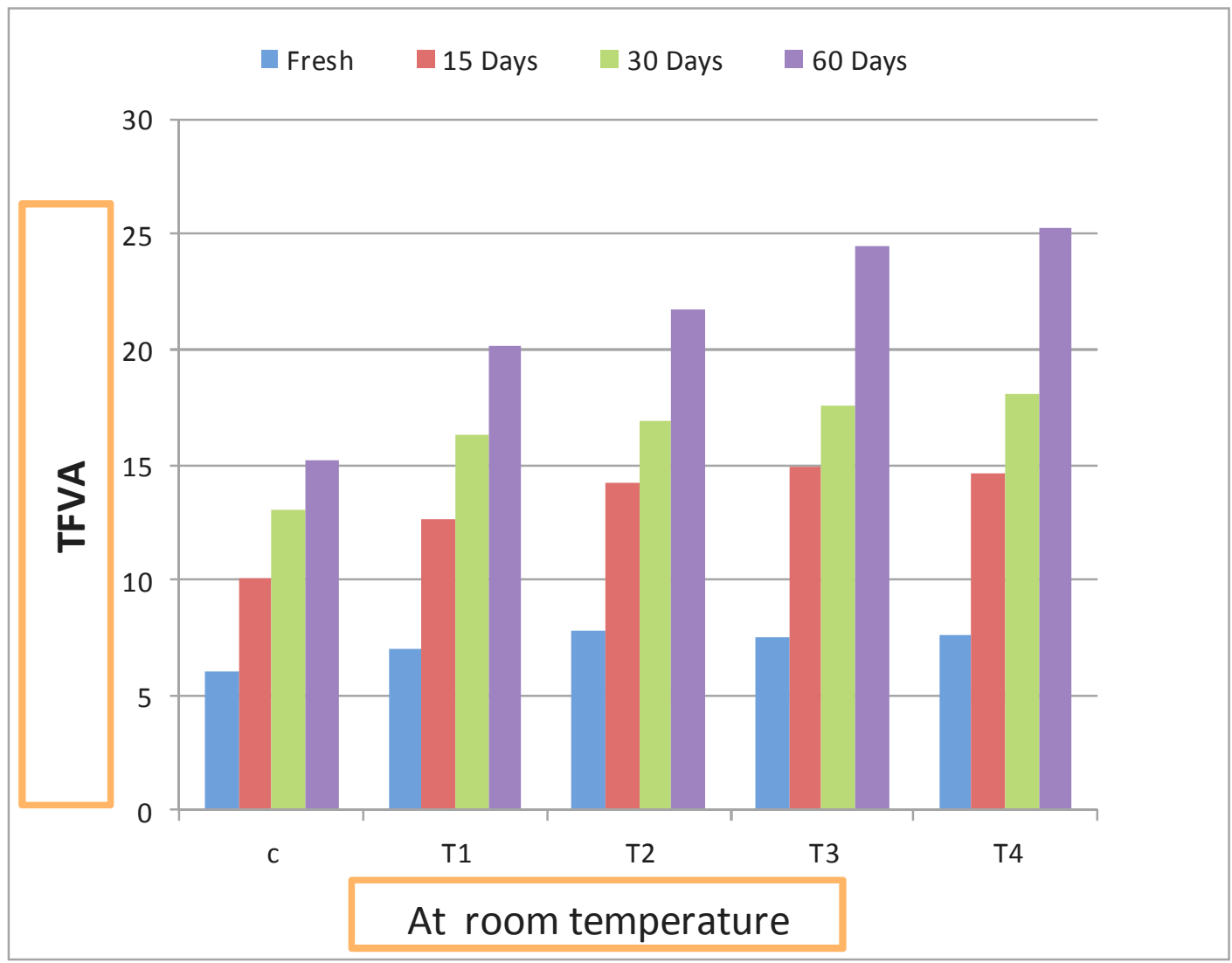

Fig (6): Total volatial fatty acids of resultant Domiati cheese held at room temperature For 60 days $(0.1 \mathrm{~N} \mathrm{NaOH} / 100 \mathrm{~g})$. 
Fig (5\&6) showed that ginger and thyme increased (T.V.F.A) contents of fresh and ripened cheese samples. It can be attributed that ginger extract contain high content of essential oil, which is a mixture of monoterpenic and sesquiterpenic compounds, and contains the volatile compounds responsible for the characteristic ginger flavor (Zancan et al., 2002).

The addition of essential oils and propolis had little effect on the composition of the resulted cheese. These results are in agreement with those reported by Ismail et al. (2006).

\section{Microbiological properties:} Table (3) exhibits the changes in counts of bacteria in all cheese samples. The viability of bacteria in both ginger and thyme fortified fresh cheese at room temperature and at $4^{\circ} \mathrm{C}$ was higher than the control and samples with propolis. During ripening the viability of bacteria in cheese fortified with propolis, ginger and thyme was less than the control. $10 \%$ propolis, $5 \%$ propolis, ginger and thyme respectively, had the highest effect on
(T.C.) especially $10 \%$. This suggested that the added spices (ginger or thyme) or propolis had antimicrobial effected on cheese microflora. These results are in agreement with Abd-alla et al. (2000), Hussein (2004) and ElSayed (2017). During ripening period, these count decreased gradually and reached its minimum level at end period of ripening. Moulds and yeasts began to appear at week 2 in control at room temperature and at week 4 in control at $4{ }^{\circ} \mathrm{C}$. However, they were not detected in propolis, ginger and thyme fortified cheese throughout the ripening period. Natural preservative are known to contain several compounds such as gingerol, gingerdiol, shogaol, thymol, $\alpha$-phellandrene and cis-sabinene hydroxide possess antimicrobial activity against food spoilage organisms (Ficker et al., 2003).

Coliforms were not detected in all cheese treatments either when fresh or during the ripening period. This may be due to the high hygienic condition during the preparation and ripening period.

Table 3. Microbial content of Domiati cheese as affected by certain natural preservatives during storage period at $4^{\circ} \mathrm{C} \pm 2$ and at room temperature.

\begin{tabular}{|c|c|c|c|}
\hline \multirow{2}{*}{ Treatments } & \multirow{2}{*}{ Days } & \multicolumn{2}{|c|}{ Total bacterial count $\mathrm{efu} / \mathrm{g}$} \\
\hline & & at $4^{\circ} \mathrm{c} \pm 2$ & At room temperature \\
\hline \multirow[t]{4}{*}{$\mathrm{C}$} & Fresh & $1.20 \times 10^{8}$ & $1.2 \times 10^{8}$ \\
\hline & 15 & $1.46 \times 10^{8}$ & $1.64 \times 10^{8}$ \\
\hline & 30 & $1.74 \times 10^{8}$ & $2.00 \times 10^{8}$ \\
\hline & 60 & $2.00 \times 10^{8}$ & $2.80 \times 10^{8}$ \\
\hline \multirow{4}{*}{ T1 } & Fresh & $1.18 \times 10^{8}$ & $1.18 \times 10^{8}$ \\
\hline & 15 & $9.0 \times 10^{7}$ & $1.60 \times 10^{8}$ \\
\hline & 30 & $7.2 \times 10^{7}$ & $1.14 \times 10^{8}$ \\
\hline & 60 & $4.4 \times 10^{7}$ & $4.0 \times 10^{7}$ \\
\hline \multirow[t]{4}{*}{ T2 } & Fresh & $1.08 \times 10^{8}$ & $1.08 \times 10^{8}$ \\
\hline & 15 & $7.8 \times 10^{7}$ & $1.20 \times 10^{8}$ \\
\hline & 30 & $5.2 \times 10^{7}$ & $8.2 \times 10^{7}$ \\
\hline & 60 & $2.2 \times 10^{7}$ & $3.6 \times 10^{7}$ \\
\hline \multirow[t]{4}{*}{ T3 } & Fresh & $1.30 \times 10^{8}$ & $1.30 \times 10^{8}$ \\
\hline & 15 & $1.00 \times 10^{8}$ & $1.94 \times 10^{8}$ \\
\hline & 30 & $7.6 \times 10^{7}$ & $1.22 \times 10^{8}$ \\
\hline & 60 & $4.6 \times 10^{7}$ & $7.0 \times 10^{7}$ \\
\hline \multirow[t]{4}{*}{ T4 } & Fresh & $1.34 \times 10^{8}$ & $1.34 \times 10^{8}$ \\
\hline & 15 & $1.10 \times 10^{8}$ & $1.72 \times 10^{8}$ \\
\hline & 30 & $7.2 \times 10^{7}$ & $1.10 \times 10^{8}$ \\
\hline & 60 & $5.0 \times 10^{7}$ & $6.4 \times 10^{7}$ \\
\hline
\end{tabular}

Molds and yeasts: Were not detected in treatments T1, T2, T3 and T4. E. coli: Was not detected in all samples. 


\section{Organoleptic properties:}

The data presented in Table (4) revealed that the control Domiati cheese gained the score as propolis, ginger and thyme fortified cheese either fresh or during ripening. In general all cheese made with different types of essential oil had acceptable appearance and body \& texture dur- ing ripening. These results are in agreement with those obtained by Ismail et al. (2006). It be concluded that propolis $(5 \%$ or $10 \%)$, ginger and thyme $0.5 \%$ essential oils can be used for improvement the quality of Domiati cheese and it can increase the shelf life of Domiati cheese for 60 days with imparting good flavor.

Table 4. Sensory evaluation of Domiati cheese as affected by certain natural preservatives during storage period at $4^{\circ} \mathrm{C} \pm 2$ and at room temperature.

\begin{tabular}{|c|c|c|c|c|c|c|c|c|c|}
\hline \multirow{2}{*}{ Treatment } & & \multicolumn{4}{|c|}{ at 4 $\mathbf{c} \pm \mathbf{2}$} & \multicolumn{4}{c|}{ At room temperature } \\
\cline { 3 - 10 } & Days & $\begin{array}{c}\text { Flavor } \\
\mathbf{( 5 0 )}\end{array}$ & $\begin{array}{c}\text { Body and } \\
\text { texture } \\
\mathbf{( 4 0 )}\end{array}$ & $\begin{array}{c}\text { Appearance } \\
\mathbf{( 1 0 )}\end{array}$ & $\begin{array}{c}\text { Total } \\
\mathbf{( 1 0 0 )}\end{array}$ & $\begin{array}{c}\text { Flavor } \\
\mathbf{( 5 0 )}\end{array}$ & $\begin{array}{c}\text { Body and } \\
\text { texture } \\
\mathbf{( 4 0 )}\end{array}$ & $\begin{array}{c}\text { Appearance } \\
\mathbf{( 1 0 )}\end{array}$ & $\begin{array}{c}\text { Total } \\
\mathbf{( 1 0 0 )}\end{array}$ \\
\hline C & Fresh & 44.0 & 34.0 & 8.5 & 86.5 & 44.0 & 34.0 & 8.5 & 86.5 \\
& $\mathbf{1 5}$ & 45.0 & 34.0 & 8.1 & 87.0 & 45.0 & 33.0 & 8.0 & 86.0 \\
& $\mathbf{3 0}$ & 46.0 & 33.0 & 7.8 & 86.7 & 46.5 & 32.0 & 7.0 & 85.5 \\
& $\mathbf{6 0}$ & 46.5 & 32.0 & 7.5 & 86.0 & 47.5 & 31.0 & 6.0 & 84.5 \\
\hline T1 & Fresh & 44.0 & 34.0 & 8.3 & 86.3 & 44.0 & 34.0 & 8.3 & 86.3 \\
& $\mathbf{1 5}$ & 45.0 & 33.5 & 8.0 & 86.5 & 45.5 & 33.0 & 7.8 & 86.3 \\
& $\mathbf{3 0}$ & 46.0 & 32.8 & 7.7 & 86.7 & 47.0 & 32.0 & 7.1 & 86.1 \\
& $\mathbf{6 0}$ & 47.0 & 32.5 & 7.5 & 87.0 & 48.0 & 31.0 & 6.8 & 85.8 \\
\hline T2 & Fresh & 44.0 & 35.0 & 8.5 & 87.5 & 44.0 & 35.0 & 8.5 & 87.5 \\
& $\mathbf{1 5}$ & 45.5 & 34.5 & 8.1 & 88.1 & 46.5 & 33.0 & 8.1 & 87.5 \\
& $\mathbf{3 0}$ & 46.5 & 34.0 & 7.8 & 88.3 & 47.0 & 32.0 & 7.5 & 86.5 \\
& $\mathbf{6 0}$ & 48.0 & 33.5 & 7.5 & 89.0 & 48.5 & 31.0 & 7.3 & 86.8 \\
\hline T3 & Fresh & 44.0 & 34.0 & 8.2 & 86.2 & 44.0 & 34.0 & 8.2 & 86.2 \\
& $\mathbf{1 5}$ & 45.0 & 33.5 & 7.7 & 85.7 & 45.0 & 32.0 & 7.6 & 84.6 \\
& $\mathbf{3 0}$ & 46.0 & 32.5 & 7.5 & 86.0 & 46.0 & 31.0 & 7.0 & 84.0 \\
& $\mathbf{6 0}$ & 47.0 & 32.0 & 7.3 & 86.3 & 47.0 & 30.0 & 7.0 & 84.0 \\
\hline T4 & Fresh & 44.0 & 35.0 & 8.3 & 87.3 & 44.0 & 35.0 & 8.3 & 87.3 \\
& $\mathbf{1 5}$ & 45.5 & 34.0 & 8.0 & 87.5 & 45.0 & 33.0 & 7.8 & 85.8 \\
& $\mathbf{3 0}$ & 46.0 & 33.5 & 7.8 & 87.3 & 47.0 & 31.0 & 7.0 & 85.0 \\
& $\mathbf{6 0}$ & 47.0 & 33.0 & 7.2 & 87.2 & 47.5 & 30.0 & 6.6 & 84.1 \\
\hline
\end{tabular}

\section{References}

Abd-Alla, M.S., K.M. Atalla, I.M. Ghazi and E.A. Galal, 2000. Effect of some aqueous plant extracts on microbiological, chemical and organoleptic properties of ultrafiltrated cheese. Annals Agric., Sci; Ain Shams Univ., Cairo 45:409420 .

Abd El-Aziz, M.; Faten L. Seleet; Sahar H. S. Mohamed and Hayam M. Abbas. 2010. Properties of functional soft cheese fortified with ginger extract. J. Food and Dairy
Sci., Mansoura University, Vol.1 (7): $429-439$.

Abd El-Aziz, M., Sahar H.S. Mohamed and Faten L. Seleet. 2012. Production and Evaluation of Soft Cheese Fortified with Ginger Extract as a Functional Dairy Food. Pol. J. Food Nutr. Sci. 62 (2) 77-83.

Abd El-kader, Y.I. 2003. Changes in the nitrogen fractions of Domiati cheese made with microbial and recombinant rennet during ripening. Egyptian J. Dairy Sci. 31: 111-124. 
American Public Health Association (APHA). 1992. Standard Methods for the Examination of Dairy Products. American Public Health Association Inc. $12^{\text {th }}$ ed., New York, USA.

Association of Official Analytical Chemists (A.O.A.C). 2000. Official Methods of Analysis. Helrichik, (ed.) $15^{\text {th }}$ edition Association of Analytical Chemists, Inc. USA PP. 777.

Association of Official Analytical Chemists (A.O.A.C). 2005. Official Methods of Analysis. (18 Edition), Published by the Association of Official Analytical Chemists, Arlington, Virginia, USA.

Awad, R.A.; S.A. El-Shabrawy, Sh.G. Osman and Suhila. A. Saad 2003. Chemical composition of flavoured processed cheese spreads with different fruit flavours. Egyptian. J. Dairy Sci., 31: 335.344.

Dabiza, M.A. 2006. Improvement of ripening and safety of Ras cheese using propolis and eugenol. Egyptian J. dairy sci., 34:185:195.

El-Sayed, A.H. 2017. Effect of Thyme on The Quality and Shelf Life of Block Processed Cheese. J. Food and Dairy Sci., Mansoura Univ. 8 (8): $335-340$.

Ficker, C.E., Arnason, J.T., Vindas, P.S., Alvarez, L.P., Akpagana K., Gbeassor M., de Souza C., and Smith, M.L. 2003. Inhibition of human pathogenic fungi by ethnobotanically selected plant extracts. Mycoses, 46: 29-37.

Fox, P.F. and Morrissey, P.A. 1976. Food analysis Dept. of Dairy and Food Chem. Univ. College. Cork Ireland.

Hussein, G.A.M. 2004. Manufacture of flavoured Tallaga cheese. Proceeding of the 9th Egyptian Conference
Dairy Science and Technology 32: 277-284.

Ismail, A. M., Harby, S. and Salem, A. S. 2006. Production of flavored labneh with extended shelf life. Egyptian Journal of Dairy Science 34: 59-68.

Ismail, A., and D.M. Pierson. 1990. Inhibition, growth and germination of C. botulinum by essential of spices. J. Food Sci. 55(6):16761678.

Jalilzadeh, A., Y. Tunçtürk and J. Hesari. 2015. Extension Shelf Life of Cheese: A Review. International Journal of Dairy Science 10 (2): 44-60.

Kilcast, D. and P. Subramaniam. 2011. Food and Beverage Stability and Shelf Life. 1st Edn., Woodhead Publishing, Cambridge, UK., ISBN-13: 978-1845697013, Pages: 864.

Kosikowski, F.V. 1982. Cheese and Fermented Milk Foods. $2^{\text {nd }}$ Ed. pp. 560-597. F.V. Kosikowski and Association, Brooktonal, New York.

Kuchroo, C.N. and Fox, P.F. 1982. Soluble nitrogen in cheddar cheese: comparison of extraction procedures. Milchwissenschaft. 37 (6): 331-335

Lawson, L. D. 1993. Bioactive organosulfur compounds: role in reducing blood lipids, in Human Medicinal Agents, 306 330, D. King horn and M. F. Balaandrin Eds., ACS symposium Series 534.

Ling, E.R. 1963. A Text - Book of Dairy Chemistry. Vol. 2, Practical, $3^{\text {rd }}$ ed., Champan and Hall, London, England.

Nicoli, M.C. 2012. Shelf Life Assessment of Food. CRC Press, Boca Raton, ISBN-13: 9781439846032 , Pages: 302.

Oleg Maksimov, 2017. Thyme Thymus vulgaris L. Thymol CT Essential Oil as Natural Preservative. 
American Journal of Essential Oils and Natural Products. 5(2): 19-22.

Papas, C.P., Kondly, E., Voustsinas, L.P. and Malletou, H. 1996. Effect of starter level, raining time and aging on the physicochemical, organoleptic and rheological properties of Feta cheese. Journal of. the Society of Dairy Technology $49,73$.

Paviani, L. C., Dariva C., Marcucci M. C., and Cabral F. A. 2009. Supercritical carbon dioxide selectivity to fractionate phenolic compounds from dry ethanolic extract of propolis. Journal of Food Engineering, 33: $15-27$.

Simov, G.U. 1980. Technological of milk products, Atext Book, Plovidiv, P. 162.

Tamime, A.; M.F. Younis, G. Davies and I. Bradbury. 1990. The quality of processed cheese made from reconstitute skim milk powder cheese base. Egyptian. J. Dairy Sci., 18:115-131.
Zakaria, A. Salih, Abdel Moneim E. Sulieman, Elamin A. Elkhalifa and Ali O. Ali. 2012. Chemical and Microbiological Characteristics of White Cheese (Jibna-beida) Produced in Sudan. Food and Public Health, 2(6): 259-264.

Zancan, K.C., Marques, M.O.M., Petenate, A.J. and Meireles, M.A. 2002. Extraction of ginger (Zingiber officinale Roscoe) oleoresin with $\mathrm{CO} 2$ and co-solvents: a study of the antioxidant action of the extracts. J. Supercritical Fluids 24: 57-76.

Zhang, X., Kilmer, R. L. and Muhammad, A. 2003. A descriptive analysis of Egypt and Saudi Arabia who import United States dairy products, monograph MGTC 03-8. International Agricultural Trade and Policy Center, Institute of Food and Agricultural Sciences, University of Florida, Gainesville. 
اطلة مدة حفظ الجبن الدمياطى المصنع باستخدام بعض المواد الحافظة الطبيعية

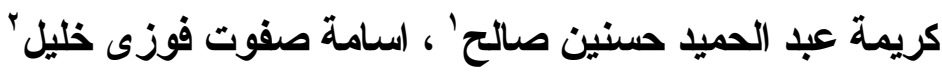

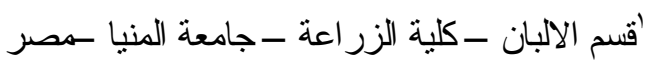

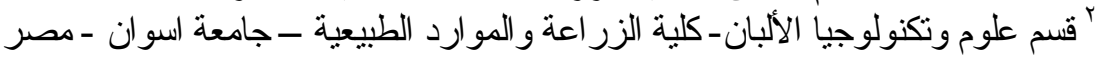

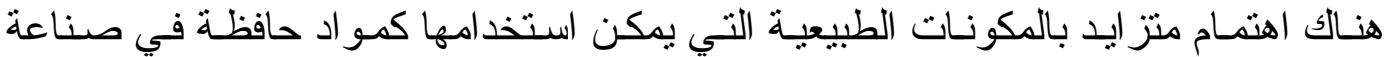

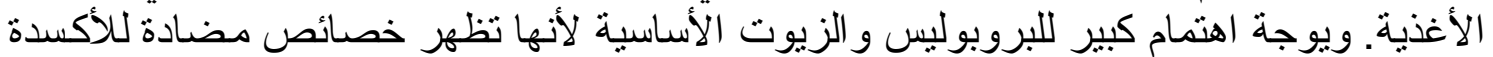

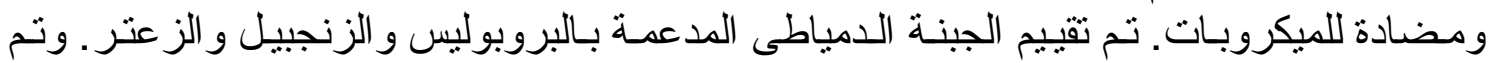

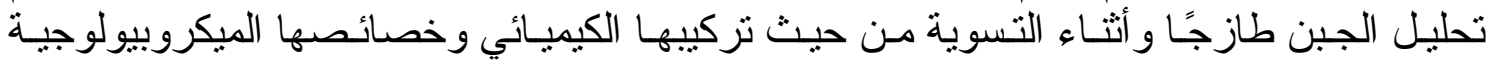

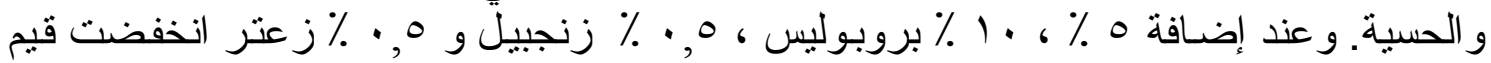

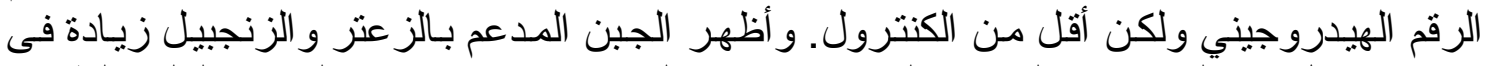

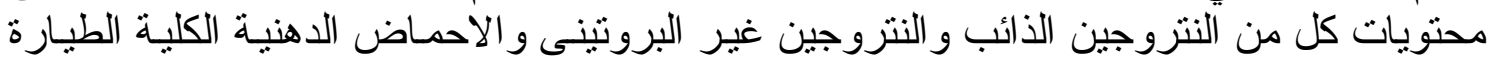

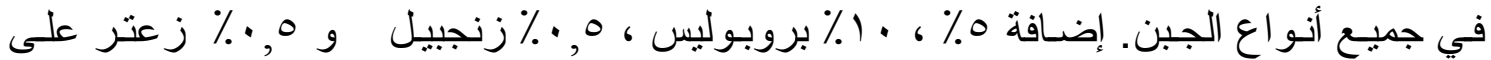

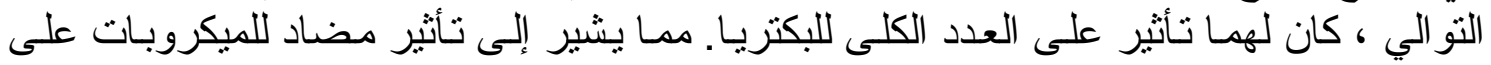

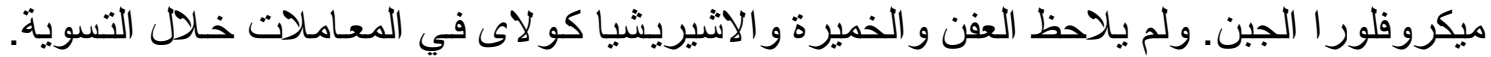

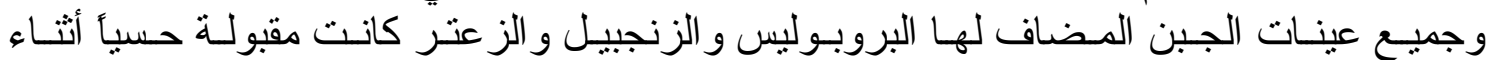

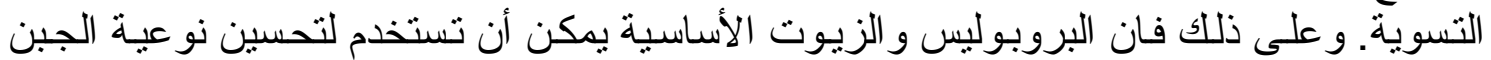

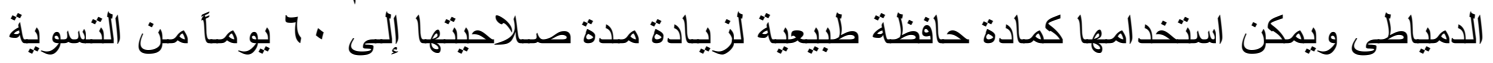

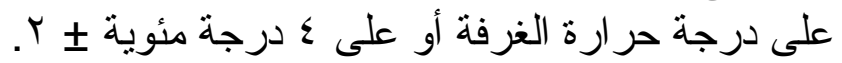

